\title{
On Sustainable Aquaculture
}

\author{
Tran Thi Nang Thu ${ }^{1}$ and Philippe Lebailly ${ }^{2 *}$ \\ ${ }^{1}$ Faculty of Fisheries, Vietnam National University of Agriculture, Vietnam \\ ${ }^{2}$ Gembloux Agro Bio Tech, University of Liège, Belgium
}

Submission: February 10, 2017; Published: February 17, 2017

*Corresponding author: Philippe Lebailly, Gembloux Agro Bio Tech, University of Liège, Belgium, Email: philippe.lebailly@ulg.ac.be

\section{Short Communication}

Aquaculture is essential to meet future demand for aquatic products. While aquaculture has expanded to supply domestic and export markets, issues concerning the limited capacity to promote and guide its sustainable development, in fresh, brackish, and marine environments [1]. World fish and aquaculture production is projected to grow at an annual rate of $1.5 \%$ during the $2016-2025$ periods (a slowdown relative to the $2.5 \%$ annually of the previous decade). Accordingly, levels of production are expected to reach 196 MT in 2025. Most of fish production's growth will take place in Asia. The majority of evolution will come from aquaculture, which will surpass total capture fisheries in 2021. Despite the increasing role of aquaculture in total fish supply, the capture sector is expected to remain dominant for a number of species, and vital for domestic and international food security. Aquaculture will continue to be one of the fastest growing food sectors despite its average annual growth rate slowing from $5.4 \%$ in the previous decade to $3.0 \%$ in the period $2016-25$.Much of the increase is expected in freshwater species. In 2025, fish originating from aquaculture is expected to represent $57 \%$ of fish consumed worldwide [2].

The development of the aquaculture sector has resulted in an increased demand for aquaculture feed. To feed the fish they produce, aquaculture enterprises often use fishmeal which is produced by reducing cached "low value" fish (thrash fish). From a food security and nutrition point of view, a key question is whether some of this thrash fish (that is currently used for non-direct human consumption) would not be more "efficient" if it was used for direct human consumption. As global fish demand increases, lower-value fish resources will experience high demand between three main destinations:

(i) The present use as animal feed - increasingly for aquaculture.

(ii) Food for human and

(iii) Food to rebuild predatory fish species stocks (e.g. tuna, cod) that is often overlooked. Alternatives for fishmeal are fish meal replacers including plant proteins, waste products from fish and terrestrial animals and the use of better/improved breeds of aquatic animals with better feed conversion.

In fact, the capture fisheries and aquaculture sectors intersect in a number of important ways. Fishmeal and oil from capture fisheries are used in feed compounds; marine space is needed by both activities and their products compete in the marketplace. The line between wild and cultured stocks is sometimes blurred by the use of restocking from hatcheries or the ranching of wild species. Aquaculture and capture fisheries production share a common market for fish and fish products [3]. The cost and availability of fishmeal and oil is a challenge to future aquaculture growth. According to the International Fishmeal and Fish Oil Organisation, replacement of fishmeal and oil is an on-going issue mainly driven by the cost of fishmeal and oil as an ingredient in the feed compounds [4]. The share of fishmeal in the overall feed mix has declined as alternative sources (mainly soybean meal) are introduced. Fish oil continues to be a key ingredient in aquaculture feed due to its Omega 3 content.

Because 'using fish to feed fish' is unsustainable, it is necessary to stimulate the production and adoption of fishmeal replacers or feeds with a low level of animal proteins. The promotion of these kinds of aqua feed for different species makes the aquaculture supply chain more sustainable. At the same time, there is an increased demand for brand, traceability, trademark and certification/sustainability among these buyers who can influence significantly the supply chain through their purchasing choices/preference. This dynamic is already being seen in some Asian countries where retailers (and in response to consumer "seafood choice" campaigns), aim to sell more eco-friendly products. However, it is unlikely that domestic consumers will take action to change the system.

This implies that reaching the goal of the sustainability of a given system is the responsibility of all participants in 
the system. These include, in the aquaculture sector, farmers, products' traders, policymakers and agricultural development stakeholders with their respective role to play in sustaining the sector. In brief, sustainable aquaculture is, not a simple model or package to be imposed but, more a process of learning and adaptation that considers together the environment, economic and social dimensions. This is the challenge not only for the aquaculture subsector but also for research units and universities.

For example, Vietnam National University of Agriculture (VNUA) is currently working with US Soybean Export Council (USSEC) to research and development of a new fish production model. The intensive pond aquaculture (IPA) technology enhances management control to yield greater fish production at lower per-unit cost through improved fish survival and feed conversion. The zero exchange system captures nutrients for use as a crop fertilizer and requires minimal use of drugs and chemicals to ensure food safety Cremer $\mathrm{M}$ et al. [5]. A demonstration in-pond raceway system to intensify and gain efficiency in pond fish production is actually under investigation in North Vietnam in collaboration with VNUA researchers. Building a comprehensive conceptual framework of sustainability development with an indicators system for measuring and evaluating the sustainability of the Vietnam's fisheries and aquaculture industry is essential. This includes not only national standards, but also a wide range of technical criteria, international norms and practices.

\section{References}

1. FAO (2014). The State of World Fisheries and Aquaculture (SOFIA).

2. OECD/FAO (2016) Fish and Seafood, in OECD-FAO Agricultural Outlook 2016-2025. OECD Publishing, Paris.

3. OECD (2015) Green Growth in Fisheries and Aquaculture. OECD Green Growth Studies, OECD Publishing, France, pp. 116

4. IFFO (2012) Aquaculture and Green Growth. Presentation given at the Green Growth and Aquaculture Workshop. Yeosu, Korea.

5. Cremer M, Chappel J, Jian Z, Enhua Z (2014) New Intensive Pond Aquaculture Technology Demonstrated in China. Global Aquaculture Advocate, p. 62.

\section{Your next submission with Juniper Publishers} will reach you the below assets

- Quality Editorial service

- Swift Peer Review

- Reprints availability

- E-prints Service

- Manuscript Podcast for convenient understanding

- Global attainment for your research

- Manuscript accessibility in different formats ( Pdf, E-pub, Full Text, Audio)

- Unceasing customer service

Track the below URL for one-step submission https://juniperpublishers.com/online-submission.php 